\title{
Device Ambient Noise Problem
}

National Cancer Institute

\section{Source}

National Cancer Institute. Device Ambient Noise Problem. NCI Thesaurus. Code C63308.

Problem associated with any undesired acoustic energy or vibration that tends to interfere with the operation of the device. 